\title{
Pedagogical Approaches in the Light of Rumi: From Reflections to Integrations
}

\author{
Siti Noor Fauziah Abd Rahima
}

\begin{abstract}
A soulful curriculum acknowledges and places an importance to life's ultimate questions and man's inner dimension. It pursues a balance and convergence between our inner and outer lives. In Islam, there is no separate discipline of ethics and religion. Islam is founded on the principles of belief and righteous action. In this sense, a meaningful education should not only focus on training the mind to retain and retrieve knowledge per se but to nurture a personality with good characters and behaviours. However, the reality that we are facing today in the education system is the reverse of that. The exclusion of ethical and spiritual dimensions in pedagogical approaches is not only observed in present practices but also in existing references, concepts, and theories in the field of education, philosophy, and psychological literature. Modern theories are inadequate to act as a drive for the transformation of an individual's personality. Therefore, this paper aimed to explore the pedagogical approaches reflected from a prominent Muslim philosopher and spiritual master, Mawlana Jalal al-Din Rumi (1207-1273 A.D) towards fostering a balanced and excellent personality through education. The main contributions of Al-Rumi that are of great importance for today's educators are: God-consciousness as the foundation of learning; the need to instill love and compassion through service learning; making learning enjoyable; and emphasis on experiential outdoor learning. Practical pedagogical implications of these were discussed in the light of educational psychology perspectives for educators to integrate these approaches in their teaching and learning activities in the classroom.
\end{abstract}

KEYWORDS: Pedagogy; Rumi; soulful curriculum; spiritual; meaningful education

a Ph.D. Researcher (Educational Psychology), Department of Educational Psychology and Counselling, Kuliyyah of Education, International Islamic University Malaysia. Email: sn.fauziah@gmail.com 


\section{Introduction}

Education is the process of growth in manifold dimensions of human being; intellectual, physical, spiritual, emotional, and social. These experiences serve as the basic elements to equip human life for living, in which through these, an individual adapts, adjusts, learns, and manages their surroundings, and makes a healthier development in life. Therefore, to ensure the experiences gained through education system are meaningful and significant, the role of teachers and the approaches undertaken are crucial.

It is without a doubt that effective and meaningful teaching which involve accomplishing what the teacher desires are among the most delicate, challenging, and exciting journey. Good teaching demands teachers to gradually become well-equipped and self-taught, develop abilities to interact with learners successfully, and deepen one's own understanding and effectiveness in coordinating various social and academic interactions. It is a matter of fact that teachers vary considerably in how they attempt to approach teaching and learning depending on a number of factors such as consideration of learner's level of development, teacher's goals and motivations, content of course materials and environmental elements such as time, physical location and resources (Petrina, 2004). Some instructional strategies adopted, to mention a few, are didactic-direct teaching which includes typical oral lecture, modelling-direct teaching that refers to visual demonstration and practice, managerial-indirect or interactive teaching which relies heavily on facilitation and sharing among learners that may include whole class discussion, individual or small group work and also dialogic-indirect interactive teaching that comprises Socratic method, questions and thought provocations (Petrina, 2004).

The great Islamic heritage indeed offers a wide-array of teaching approaches to be explored and practiced by teachers especially for reflective practices which emphasize ethical and spiritual values as the core. Islamic past civilization which started centuries ago had once reached its peak of civilization known as Golden Age of Islam during the reign of Caliph Harun al-Rashid (786-809 A.D) and succeeded by his son, al-Ma'mun, reigned from 813-833 A.D (Tschanz, 2003). The legacy of Muslim pursuit of knowledge was then continued by renowned 
Muslim philosophers and scientists like Al-Khawarizmi (d.850 A.D), Al-Kindi (d.873 A.D), Ar-Razi (d.925 A.D), Al-Farabi (d.950 A.D), Ibn Sina (d.1037 A.D), Ibn Haitam (d.1040 A.D), Al-Ghazali (d.1111 A.D), Ibn Tufayl (d.1185 A.D), Ibn-Rushd (d.1198 A.D), and Ibn Khaldun (d.1406 A.D). These great minds indeed had embarked on scholarship journey and contributed their valuable thoughts and innovations through diverse disciplines such as kalam, philosophy, education, eschatology, political philosophy, medicines, physics, astrology, chemistry, algebra, and many more. These passions and intensities that previous Muslim legacy brought to every field of life endeavours had undeniably produced tremendous lessons and reflections for today's applications and should be explored, presented, and integrated into our current practices and curriculum for effective instructions and betterment of Muslim Ummah.

\section{The Purpose of the Paper}

This paper intends to analyse some practical pedagogical approaches from significant works of renowned Muslim polymath and intelligentsia; Mawlana Jalal al-Din Rumi (1207-1273 A.D). Rumi was born in the heartlands of Khurasan in Persia, fascinated not only in the Muslim world but also globally due to his universal messages he conveyed and the use of metaphors derived from sources that mostly shared by human experience (Rumi \& Chittick, 1983). In Islamic history, there are other thinkers from other corners of the world; however, this writing focuses on this prominent intellectual figure as he exemplified interesting notions to benefit soulful and reflective pedagogical approaches for today's practices. In an attempt to analyse Rumi's pedagogical approaches, the focus of this writing would be based on his spiritual values which have guided his views on the nature of human being, the reality of truth, and the relationship of a man with fellow man and a man with God. This paper also outlines some practical pedagogical approaches in the light of educational psychology perspectives as the guidelines and recommendations for educators.

\section{Rumi: Centennial Review and Lifetime Works}

Jalal al-Din Rumi (known as Rumi) (1207-1273 A.D), is one of the utmost spiritual masters in Islam, and the most celebrated and studied mystical intellectuals in the West and Orientalist after al-Ghazali, perhaps (Chittick, 2005). Rumi was born in Balkh, Khurasan in Persia, in 1207 A.D into a religious family, especially the father, Baha'al Din 
Walad, a man who is acknowledged for his knowledge and himself as a Sufi. The family moved and settled in Konya (in the present day, known as Turkey) after the conquest of Mongol when he was 6 years old. Interestingly, traces of Sufi's descent and religious scholarship on Baha'al Din Walad have found its trail to al-Ghazali as Baha'al Din Walad was unexpectedly involved in the several feuds with Fakhruddin al-Din al-Razi (d.925 A.D) who attacked al-Ghazali's rigorously on the philosophers, especially Ibn Sina (Arberry, 1961).

Rumi, under his father's grooming, learning, and piety during his early age, had studied deeply important poem of mystical life from which he was very fascinated. His father wedded him (18 of age) to a daughter to Lala of Samarqand, apparently a member of the fugitive party, Gauhar Khatun (Arberry, 1961). After the demise of his father in 1231 A.D, Rumi at the age of 24 succeeded his father erudite position and religious duties. Since then, Rumi became more engrossed with Sufi's teaching like his father, and became the disciple of various spiritual masters during his time. Rumi was also reported to be one of the disciple of his late father's follower, Sheikh Burhanaddin-I Muhakkik-I Tirmidhi (known as Sayyid-I Sirdan) (Citlak \& Bingul, 2014). At the same time, Rumi expended successful time with his followers and colleagues and established his reputation as a prominent figure in Konya. Rumi's social life began when he was hired as an Islamic Jurist, assigning fatwas, and delivering lectures in the mosques of Konya. He also was an Islamic preacher and taught his students in the madrasah.

The most significant occasion that happened to Rumi was in 1244 A.D. when he was 37 years old. He met Shamsaddin Muhammad-I Tabrizi, or Shams of Tabriz, in Konya. The prompt outcome of that deep spiritual and emotional experience had changed the chart of his life from an established teacher and jurist into an ascetic as expressed in the first verses by Shams, according to the version of Sultan al-Walad (Rumi's son), as follows;

Suddenly Shamsaddin came and reached him; shadow perished in the light of his light. The sound of love, free of tambourine and saz (a stringed musical instrument), came, emulating, the world of love. 
He explained him in the states of the Beloved; thus ascended his secret to the highest of the highest, He said: You have become a hostage of the inward; but know that I am an inward" (Citlak \& Bingul, 2014).

Rumi has been described by notable accounts for being an acquaintance to Shams of Tabriz for more than two years in which he learned a remarkable devotion and love. Both of them remained inseparable. The mysterious Shams of Tabriz, cut off Rumi's attention in entirety to his teaching, religious duties, and his circles which stirred up threats of violent among Rumi's followers to Shams of Tabriz. The outburst jealousy eventually made Shams of Tabriz left Konya and fled to Damascus but he had been brought back by Sultan al-Walad, the son of Rumi. The followers of Rumi repented only for a short period and assailed this intruder once again, causing Shams of Tabriz to disappear for the second time, eventually without any trace behind this time (in 1947 A.D). The departure and disappearance of Shams of Tabriz had affected Rumi badly in which he illustrated his longing for the bosom friend in his couplets in Divan-I Sham-I Tabriz (Aksoy \& Tenik, 2002).

Rumi's influential work, Divan-I Sham-I Tabriz which consisted of 40,000 couplets, started from his expressions outpouring his feeling in the form of ghazals (Persian poems). After searching for Shams of Tabriz couple of times, Rumi came into realization of his departure and accepted the fact. Rumi later made deep companionships with Salah alDin Faridun Zarkub (d.1258) and Hussam al-Din Chelebi (d.1284-850) (Papan-Matin, 2003, p.246). Hussam al-Din Chelebi was his favourite student and he had encouraged his Master, Rumi to write a book as a console to many readers. Thus, Rumi started to compose his Masnavi which dictated six volumes (25,700 couplets) of his 12 years of work in Anatolia. Rumi fell ill in 1273 A.D. and died in the same year in Konya, his body was buried beside his father, and a splendid tomb was constructed over his place of burial.

Rumi, has been speaking to people from various backgrounds and cultures through the language of love in his works for centuries. Rumi, as he is known mostly as Rumi in the Western world and Mawlana in the Eastern world, is one of the extraordinary persons who had applied a great inspiration on both space and time; in fact, his works are more revealing now as he is better known in the modern world. Rumi's path of love within Sufism's breadth has always fascinated millions of people 
all over the world. Rumi's divine love calls not only for theory but also for operative system. Among them are the union with God, the nafs, the knowledge and method, and the limitations of rational knowledge. The knowledge and method for instance, take the heart as the core and central of a human being. It is identified according to the Sufi's point of view as the innermost nature of a man in which holds the man's archetype or principal possibilities links him directly to the world of Spirit (Chittick, 2005).

Rumi's studies among German orientalists, in particular Friedrich Ruckert (d. 1866), managed to present the divine love uttered by Rumi in his poems to the Germans by employing the couplet form in Germany for the first time. Ruckert learned Persian, Arabic and, Turkish in order to understand more Rumi's masterpieces and later on translated forty-four of Rumi's couplets into the German verse (Arberry, 1961). Furthermore, Ruckert also sought to exemplify Europeans the prominence of the Sufis of Islam and made them feel the divine love described by these Sufis. Another orientalist, Professor Annemarie Schimmel has also published a substantial number of books and articles on Rumi in several languages; German, Turkish, and English (Arberry, 1961).

\section{Rumi and Pedagogical Approaches}

Rumi's view on reason is a faculty which is centred in the heart and not in the mind. It exists in a man so he can distinguish between real and unreal. A man's desire and ego are often in conflicts which can distract him from the true knowledge. The true intelligence, according to Rumi, is to see things as they are through God and it cannot be other than him (Chittick, 2005). To Rumi's observation, God is as the Sun where in order to reach it, the veil of symbols is essential and referring to Schimmel (1980), Rumi's allusion of symbols are the every signs and events on earth. Indeed, these symbols and signs on earth can convey such powerful meanings, help a learner to understand different aspects and attributes of God as well as to approach the true knowledge. In other words, the process of learning should inform a man about himself, his surrounding world, other creations and the purpose of existence which at end these understanding should bring him closer to God, the real Truth.

Reflecting Rumi's inspirational messages and bold adaptations of poetic odes into pedagogical practices in present-day, there are four 
integrations that could be implemented in educational settings; (1) drive holistic excellence through God-consciousness in life and actions, (2) create enjoyment in learning through self-regulation, (3) instil love and compassion through service-learning, and (4) reveal the Truth through outdoor learning in nature. These practices could occupy as indirect instruction and be applied as a complement element of other teaching methods. Guided by educator, these four integrations would facilitate learning by giving opportunities for learners to connect between theory and action, to construct their understanding of themselves and the world around them, to discuss their emotions, to critically evaluate their perspectives, to reflect their values, beliefs and apprehensions, to invoke the inner soul, and to transform a learner to be a better person accordingly. Henceforward, the treatments of Rumi's pedagogical approaches in this following discussion are derived from the reflections of his selected poems and couplets; the Divan-I Kebir, Meter 1 and Masnavi i Ma'navi.

\section{Reflecting Rumi: Applications in Today's Education Setting}

\section{Drive Holistic Excellence through God-Consciousness in Life and Actions}

How we think about ourselves and how we behave can determine how we think about God. How we perceive God in our mind can affect our self-understanding. The cardinal importance of all religious belief in this world put emphasizes on knowing ourselves. This is very crucial for spiritual growth and also for personality or self-development; in other words, makes a person ethical. The state of shaping ourselves indeed needs justification and mirror as it reflects the perfection. Having God consciousness or God presence in everyday life is a motivation for human beings to strive and to actualize the potentials given by God to the fullest degree.

Rumi's love and admiration for God combined with his poetic magical charms transpire in his insight that love is an inspired power and the raison d'être of the whole existence and it encompasses all beings in this universe (Anushiravani \& Nasseri, 2005). A man's potentials for growth and development become active and meaningful through the acknowledgement of God's traits in oneself through the internalization of God's attributes in a man. In order to reach this manifestation, 
travellers (Salik) should disengage themselves from the rust of this worldly life and set themselves free in order to allow the 'divine light' enters their hearts and leads them towards the source of that light. Rumi describes;

When the body bows in worship, the heart is a temple,

And where there is a temple, there bad friends are weeds

When a liking for bad friends grows up in you,

Flee from them, and avoid converse with them.

Root up those weeds, for, if they attain full growth,

They will subvert you and your temple together.

(Masnavi i Ma’navi, 2001, Book Four, p.276)

True reason is to be found where $\mathrm{He}$ is.

Men of wisdom direct their reason heavenwards,

Vain babblers halt on earth where no "Friend" is.

(Masnavi i Ma'navi, 2001, Book Four, p.279)

These two stanzas could be referred as unveiling and divine exposure which directs a man to the path of God. This type of experience and acquisition leads one to love and feel the God's presence in his heart. And when the heart is enlightened by God's light, actions by body and taught by reason would be reflected on its faithful engagements with an endless range of beautiful manners and etiquettes. Therefore, the process of teaching and learning should translate this concept of Godconsciousness in the daily life of each and every learner not only to inspire them to strive for excellence and determination in their study but also to manifest this awareness into virtuous actions, peaceful heart and serene taught as illustrates in the below stanza;

The knowledge of men of heart bears them up,

The knowledge of men of the body weighs them down.

When 'tis knowledge of the heart, it is a friend; 
When knowledge of the body, it is a burden.

(Masnavi i Ma'navi, 2001, Book One, p.77)

Therefore, in order to draw reflection about God in learners' minds through classroom practices, course materials and learning processes involved in classrooms are crucial. Learning through reflection according to Rogers (2001), is the process that could allow the learner to "integrate the understanding gained into one's experience in order to enable better choices or actions in the future as well as enhance one's overall effectiveness" (as cited in Ash and Clayton, 2004). This process which is known as ABCs approach comprises three important components namely; (1) affective (exploring learner's feelings and emotions), (2) behavioural (action) and (3) cognitive (the learning input) (Welch, 1999). The ABCs approach is a generic template to assist learners to evaluating their reflective process (Welch, 1999). In essence, reflection process requires active contribution of a learner to drive forth their thoughts to critically make careful considerations, generalizations, correlations, comparisons and evaluations of their past experiences and memories, interrogate their feelings and eventually prompted these elements to consider how their beliefs, knowledge, learning inputs and actions have shaped the interpretation and apprehension of an issue of concern in their life (Mezirow, 1990) and could perhaps results in a changed of conceptual perspective (Boyd \& Fales, 1983). There are numerous methods of reflective activities that could be planned carefully in classroom to accommodate this orientation such as reading, writing and learning by doing to fit learner's preferred learning styles. Among these activities are journals, quotes exercises, reflective essay, directed readings, photo reflections, structured classroom discussions, classroom presentations, guided imagery, 3 minutes speeches, building solutions and life stories (Reed \& Koliba, 1995).

Consequently, teachers' role is essential as a democratic and nondirective facilitator as described by Brookfield (1995) in reflective process. More importantly, in order to foster God-consciousness through this process among learners, a teacher should be able to bring out the three important components of reflective process mentioned before through reflective activities and guide the rumination of leaner's beliefs, experiences, values, personalities and knowledge by placing them 
within a broader and more meaningful understanding of the purpose of existence including themselves as human beings, other humankind and other creations in this Universe. The aim of this process is to instil a constant reference to God in learner's heart and mind, to ensure that knowledge he or she seek and everything he or she does is in accordance with God's pleasure. Through this process, it is hope to strengthen the inner submission and love for God and mirrored as godliness characters in deeds which ultimately would produce a harmonized and holistic learner who understand profoundly his or her roles coming to this world and excels in performing the roles by using all the tools (sight, hearing, thinking etc.) given to him or her excellently.

\section{Create Enjoyment in Learning through Self-Regulation}

Self-regulation could be understood as self-rule or self-autonomy. It is an internal process of deliberation within an individual, thus signifies that an individual is capable of independent functioning (Bodrova \& Deborah, 2007; Gillespie \& Seibel, 2006). Rumi argued that every creature has a special force and form of free will. According to him, a being will be elevated gradually, in stages by God's will. He asserted that, one's justification and decision should be respected if it is taken autonomously with 'ilm (knowledge) and that person has to hold the responsibility for it;

Freewill is as the salt to piety,

Otherwise heaven itself were matter of compulsion.

In its revolutions reward and punishment were needless,

For 'tis freewill that has merit at the great reckoning.

If the whole world were framed to praise God,

There would be no merit in praising God.

(Masnavi i Ma'navi, 2001, Book Three, p.224)

In an educational setting, self-regulation is related to a complex processes which allow a learner to appropriately respond to their surrounding environment (Bronson, 2000). Derryberry and Reed (1996) referred to this capacity as 'thermostat' which regulates by sensing and measuring immediate temperature and compares its reading to 
a present ambiance. With appropriate social skills acquire through educational process, regular practices and everyday experiences, these elements will prepare a learner to receive and adapt to any possible situations. In early childhood education context, for example, children improve their self-regulation as they are exposed to more socialized environment compared to home setting. Children are expected to familiarize themselves to the new environment by collaborating with the group members in doing tasks, interacting with friends and teachers during classroom activities, as well as expressing their emotions and sympathy throughout their time spent in school. Indeed, the classroom environment serves as a constructive field for children to learn selfregulation as learning activities take place there.

However, children are young creatures who are young and fresh to undertake their self-regulation by themselves. Therefore, the role of teachers in helping children to manage their emotions and bodily functions are crucial and undeniable in order to avoid ongoing stressful feeling in children which could lead to mental difficulties (Kostelnik, Whiren, Soderman, Stern \& Gregory, 2002). Children are vulnerable to some little things in the eyes of elders; they could cry and feel deeply sadden with the loss of their pet, family or friends separation or even change in their napping time. Children could exercise external behaviours such as throwing a tantrum or crying loudly and internal behaviours such as avoiding people or be in a silent mode. Hence, how teachers can help to recover this stressful state? Rumi in two of his beautiful verses recite;

Actions go with ideas; Goods come from the earth.

This situation appears in words; The words are the sign of situations.

(Divan-I Kebir, Meter 1, 1995, Vol.1, Verse 1, p.3)

Touch your cheek to the cheek of sugar.

Get the taste of it. Give perfume to it.

Try to alleviate the pain of separation

With the help of sugar. 
(Divan-I Kebir, Meter 1, 1995, Vol.1, 4 Verse 73, p.11)

From these lovely words, they have implied that teacher could play a role in calming down the children through positive responses with gentleness and kindness in words and actions. With soft spoken words, attend with tenderness in behaviour such as holding their hands, responding attentively, and hugging them, children learn how to regulate their feelings, they reconnect with their teachers after a stressful event and feel safe in a new situation, and trust that their teacher will take care of them and move on from their distractions. Children learn to regulate their temporary distressful emotions through overcoming their small conflicts in everyday life and with teachers support, it will help them to feel better and to cope with bigger future challenges. In brief, Rumi's wisdom recommends to attend to children's emotion as it teaches them to learn through pain, embrace the process, mend the distress and enjoy learning process in contentment.

\section{Instil Love and Compassion through Service-Learning}

Rumi's teaching appeals for love and compassion of human being with God and also with fellow man. Good deeds and acts of benevolence are the essential subjects for ethical and morality theories which uphold good deeds for mankind in general. Rumi believed that religion is not only for a certain group of people or ethnic group but it is also for all humanity. Every deed begins from God and proceeds to Him. Thus, the purpose of life is to make a meaning and be better than the previous day. Doing good things is a form of 'ibadah (religious duty) as it is commanded by God and definitely no good deed for the sake of God will be unrewarded. For Rumi, he describes the good exemplar for this noble action was Prophet Muhammad (pbuh) who has been sent by God as "a Mercy for all creatures" (Qur'an, al-Anbiya', 21: 107) as he depicts in his verse in Divan-i Kebir;

Look at the One

Who is the compassion of the universe.

Look at how He uplifts, gives status to the poor.

Mantles are as bright as the moon. 
Shawls smell like roses.

(Divan-I Kebir, Meter 1, 1995, Vol.1, Verse 1, p.3)

Speaking of the educational application on this notion, pedagogical approaches should encourage and foster learners to be conscious, internalize good values, and develop the sense of civic responsibility. Service-learning is "a structured learning experience that combines community service with explicit learning objectives, preparation, and reflection. Learners engaged in service-learning are expected not only to provide direct community service but also to learn about the context in which the service is provided, the connection between the service and their academic coursework, and their roles as citizens" (Seifer, 1998). This service-learning strategy adopts experiential learning, learning through actions, and learning a process which integrate learners' experience through effective change, develop a sense of belonging, as well as improve their skills.

By using service-learning as one of the pedagogical approaches in learning, learners do not only obtain knowledge for themselves through acquisition of facts, information, skills, and self-esteem, they also have the opportunity to link service experiences to the academic content of a classroom (Barret, 2002). In addition, service-learning is important as it moves beyond the four walls learning in normal classrooms. The inspirations could touch the heart of learners in which the pursuit of making difference in the community becomes the way of life, they obtain the soul-infused personality, encourage them to reflect on the reality of life, learn to operate with humility and compassion, nurture their ego to be in harmony with the soul in a positive manner, and foster them to be a good citizen by creating a better place of living and by contributing to alleviate community urgent needs as conveyed by Rumi's message of love and compassion through his wisdom;

If you sow one seed,

You'll harvest a hundred ears of com.

Why are you scratching your ear?

Give something to the poor. 
Give a little, see more returned.

Make heart, watch being praised.

Solve problems, see your problem solved.

Come, give something to the poor.

Respect, you'll be respected.

Bless and you'll be blessed.

Show compassion, you'll get the same.

Give something to the poor.

(Divan-I Kebir, Meter 1, 1995, Vol.1, 4 Verse 73, p.615)

Undeniably, Rumi message of love and compassion could be realized by practising service-learning in more creative and effective ways depending on the target groups as well as the objectives to accomplish.

\section{Reveal the Truth through Outdoor Learning in Nature}

Rumi's teachings drive for seeking knowledge of Truth through contemplating over the signs and symbols on earth that could only possibly attained by using physical senses and faculties of learners such as sight, hearing, smelling, savouring, touching and reasoning. Foundational to this, Rumi also encouraged a man to strive to be in the path in order to disclose the boundaries of physical senses and faculties and to attain the true knowledge (Chittick, 2005).

As a matter of fad, He is the one who asks and desires.

We are like shadows.

All our talks, our conversations belong to the Beloved.

In reality, $\mathrm{He}$ is the One who does the talking.

He tells about Himself.

Sometimes we go to the creek of the Beloved,

Like a cascading, running stream.

Sometimes we fill the jar of the Beloved, 
Like water, and stay still there.

Sometimes we are boiled down like

Water in a cooking pot.

He stirs us with a skimmer.

That's the habit of the Beloved.

He puts His mouth to our ear,

Keeps saying something in order

To have our soul get the smell the Beloved.

(Divan-I Kebir, Meter 1, 1995, Vol.1, 15 Verse 2473, p.656)

The universe is like a mirror.

Love is the reflection of Absolute Beauty.

O people, why should the One who sees the whole

Look only at the parts?

Be on foot, like the green

At this rose garden;

Because the Beloved is the only one

Who rides a horse.

The rest of them here are on foot.

(Divan-I Kebir, Meter 1, 1995, Vol.1, 99 Verse 3038, p.406)

Look at the particles on the earth,

How they move and dance.

Once this group stops, new ones come. 
Light and exaltation for the Soul

Are from Him on the earth.

Time and power to grow the body,

Like a seed under the ground

Are also from Him.

(Divan-I Kebir, Meter 1, 1995, Vol.1, 74 Verse 680, p.555)

Learners learn best when they could connect what they learn with the real context of applications. By taking a significant wisdom of Rumi's ideas on the fact that our physical and rational abilities are illusions of the true knowledge, outdoor learning appears to have the quality of "eco-spirituality" and an apt context for learning where learners may not only discover natural creations in their environment but also understand the God's signs (ayaat) in nature as the the Open-Book as explains in Qu'ran in surah Al-Baqarah (2:164):

Behold! In the creation of the heavens and the earth; in the alternation of the night and the day: in the sailing of the ships through the ocean for the profit of mankind; in the rain which Allah sends down from the skies, and the life which He gives therewith to an earth that is dead; in the beasts of all kinds that He scatters through the earth; in the change of the winds, and the clouds which they trail like their slaves between the sky and the earth;-(Here) indeed are Signs for a people that are wise.

Nature has significant resources of real and concrete materials for learners to enhance their learning experiences through natural world engagement. Events such as playing in the field and woods, greening activities, rambling freely to the nearest streams, forest or bushy areas, and educational trips offer a suitable platform for learners to discover their abilities, learn, and relate to different things in nature with minimal assistance from their teachers. Numerous studies have revealed that outdoor learning activities which take place in natural setting has a great potential to provide plentiful significant, positive and, effective impacts on children cognitive and socio-emotional development (Bergen, 2002; Harrington, 2009; Blair, 2009; Munoz, 2009; Charles, Louv, Bodner \& Guns, 2008; Kellert, 2006). 
Through choosing outdoor learning activities freely, children learn and absorb information by integrating natural world experiences with the subject matter, for example, seeing and trying out the processes and be in the real context. They also learn some necessary skills for their adult life such as problem-solving, leadership, self-esteem, teamwork, self-confidence, social competence, and safety. Outdoor activities also offer children the chance to discover their community, appreciate their sensory experiences with plant, water, sand, and mud, create their own places for play, gather stuff and develop favourite pastimes, increase their liking for physical activity, and emphasize the interconnectedness of all things (Clements, 2004).

At an age where technology grows rapidly and children regularly stare at screens, outdoor learning activities bring the children outdoor to learn in a natural atmosphere. According to Richard Louv, in his book 'Last Child in the Woods', he describes human beings, particularly children, who spend less time outdoors, resulted in many problems such as attention span issues, childhood obesity, and depression. This has been termed as 'nature deficit disorder' (Louv, 2008). Promoting outdoor learning activities to a typical restrained classroom can give a lot of benefits in terms of living healthily and encouraging children's aesthetic appreciation of nature. Richard Louv calls for more outdoor classroom to be implemented by teachers in school due to the positive consequences and advantages for children and their learning experiences, as well as their development.

In sum, Rumi calls for a return to nature as it has more to offer, not just for physical, emotional, and intellectual development of a learner, but also to nurture and cultivate their spiritual domains.

\section{Conclusion}

The positive aspects of Muslim historical accounts and past civilization should be learned, reflected, and treasured. Same goes for the advice and pedagogical approaches that have been highlighted by a Muslim philosopher and a great thinker in this paper in order to produce a harmonious and well-rounded personality through the education system. Rumi's approaches encompass the acknowledgement of the purpose of life through God-consciousness and have a balanced knowledge for livelihood and also for hereafter. The pedagogical approaches by Rumi 
are like whispering breezes; they are discrete, hush, soft, and indirect which work from 'within oneself' or 'teaching from the heart' through transforming a human being by the love of God to the love of the whole humanity.

\section{REFERENCES}

Aksoy, S., \& Tenik, A. (2002). The four principles of bioethics as found in 13th century Muslim scholar Mawlana's teachings. BMC Medical Ethics, 3(1), 4. Retrieved from http://bmcmedethics.biomedcentral.com/ articles/10.1186/1472-6939-3-4

Anushiravani, A., \& Nasseri, F. (2005). A Comparative Reading of George Herbert's and Rumi's Epistemology of Divine Love, Journal of Religious Thought: A Quarterly of Shiraz University, 30, 1-28. Retrieved from https://www.academia.edu/17962911/A_Comparative_Reading_of_ George_Herbert_and_Rumis_Epistemology_of_Divine_Love

Arberry, A. J. (1961). The Discourses of Rumi (Fihi mafihi) (translated). Routledge Curzon.

Ash, S. L., \& Clayton, P. H. (2004). The articulated learning: An approach to guided reflection and assessment. Innovative Higher Education, 29(2), 137-154.

Barrett, R. (2002). Implementing Cultural Transformation: Building a Visionguided, Values driven Organization. Richard Barret and Associates LLC, USA.

Bergen, D. (2002). The role of pretend play in children's cognitive development. Early Childhood Research \& Practice, 4(1), n1. Retrieved from http:// ecrp.uiuc.edu/v4n1/bergen.html

Blair, D. (2009). The child in the garden: An evaluative review of the benefits of school gardening. The Journal of Environmental Education, 40 (2), 15-38. Retrieved from http://www.tandfonline.com/doi/abs/10.3200/ JOEE.40.2.15-38\#.Vr1JwP197IU

Bodrova, E., \& Deborah J. Leong. (2007). Tools of the mind. Columbus, OH: Pearson.

Boyd, E. M., \& Fales, A. W. (1983). Reflective learning key to learning from experience. Journal of Humanistic Psychology, 23(2), 99-117.

Bronson, M. (2000). Self-regulation in early childhood: Nature and nurture. Guilford Press. 
Brookfield, S. (1995). The getting of wisdom: What critically reflective teaching is and why it's important. Becoming a critically reflective teacher, 1-28.

Charles, C., Louv, R., Bodner, L., \& Guns, B. (2008). Children and Nature 2008.A Report on the Movement to Reconnect Children to the Natural World. Santa Fe: Children and Nature Network, 9-11.

Chittick, W. C. (2005). The sufi doctrine of Rumi. World Wisdom, Inc.

Citlak, M. F., \& Bingul, H. (2014). Rumi and his sufi path of love. Işı1k Yayıncılık Ticaret.

Clements, R. (2004). An investigation of the status of outdoor play. Contemporary Issues in Early Childhood, 5(1), 68-80. Retrieved from http://www.imaginationplayground.com/images/content/2/9/2960/Aninvestigation Of-The-Status-Of-Outdoor-Play.pdf

Derryberry, D., \& Reed, M. (1996). Regulatory Processes and the Development of Cognitive Representations. Development and Psychopathology, 8, 21534.

Gillespie, L. G., \& Seibel, N. L. (2006). Self-regulation: A cornerstone of early childhood development. YC Young Children, 61(4), 34. Retrieved from http://journal.naeyc.org/btj/200607/Gillespie709BTJ.pdf

Harrington, M. C. (2009). An ethnographic comparison of real and virtual reality field trips to Trillium Trail: the salamander find as a salient event. Children Youth and Environments, 19 (1), 74-101.

Kellert, S. R. (2006). Building for Life: Designing and Understanding the Human-Nature Connection. Renewable Resources Journal, 24(2), 8.

Kostelnik, M. J., Whiren, A. P., Soderman, A. K., Stein, L. C., \& Gregory, K. (2002). Guiding children's social development: Theory to practice. New York: Delmar.

Louv, R. (2008). Last child in the woods: Saving our children from naturedeficit disorder.

Mezirow, J. (1990). How critical reflection triggers transformative learning. Fostering critical reflection in adulthood, 1-20.

Munoz, S. A. (2009). Children in the Outdoors. London: Sustainable Development Research Centre.

Papan-Matin, F. (2003). The Crisis of Identity in Rumi's Tale of the Reed. Comparative Studies of South Asia, Africa and the Middle East, 23(1), 246-253.

Petrina, S. (2004). Curriculum and instruction for technology teachers. Retrieved from http://www. cust. educ. ubc. ca/programs/tsed/research/ books 
Reed, J., \& Koliba, C. (1995). Facilitating reflection: A manual for leaders and educators. John Dewey Project on Progressive Education and Educators, University of Vermont. Retrieved from http://www.uvm.edu/ dewey/ reflection_manual/

Rumi, J.A. D. (1995). Divan-I Kebir, Meter 1, Translated by Ergin, N.O.Turkish Republic, Ministry of Culture \& Walla Walla, WA.

Rumi, J. A. D. (2001). Masnavi i Ma'navi, Teachings of Rumi, The Spiritual Couplets of Maulana Jalalu-'d-din Muhammad I Rumi, Translated and abridged by Whinfield, E.H. Iowa: Omphaloskepsis, E-Book. Retrieved from http://www.omphaloskepsis.com/Library/masnavi.pdf

Rumi, J. A. D., \& Chittick, W. C. (1983). The Sufi path of love: The spiritual teachings of Rumi. Suny Press.

Schimmel, A. (1980). Triumphal Sun, The: A Study of the Works of Jalaloddin Rumi (No. 8). Suny Press.

Seifer, S. D. (1998). Service-learning: Community-campus partnerships for health professions education. Academic Medicine, 73(3), 273-7.

Tschanz, D. W. (2003). Hunayn bin Ishaq: the great translator. Journal of the International Society for the History of Islamic Medicine, 1, 39-40. Retrieved from https://www.academia.edu/1150211/Hunayn_bin_Ishaq The_Great_Translator

Welch, M. (1999). The ABCs of reflection: A template for students and instructors to implement written reflection in service-learning. NSEE quarterly, 25(2). 